\title{
REFLECTIONS ON THE GLOBAL ART \\ MARKET: implications for the Sociology of Culture
}

\section{Diana Crane*}

\begin{abstract}
The article examines the recent changes in art world from the characteristics of the global art market and its implications for sociological theories of art. Therefore, it focuses on the correlation established between the decline of the avant-garde art and how there are tenuous boundaries between high culture and popular culture. In this sense, it discusses and analyzes the influence increasingly exerted by actors located in countries such as the United States, England, Germany, France and, more recently, China. It concludes with how much the global art market may be illustrative of cases in which the globalization of markets expands the cultural and economic inequality by favoring the privilege of small social groups in the contemporary world.
\end{abstract}

Keywords: change; world of art; global art market; avant-garde art; high culture; popular culture; borders; social theories about art.

Recent changes in the market for contemporary art have implications for our understanding of how art markets operate, how reward systems in the arts are changing, the extent to which avantgardes are declining, and the ways in which high and popular culture can be distinguished. There is now a global market for contemporary art in which the most influential actors are located in the United States and a few other countries, primarily England, Germany, France and, recently, China (Ballet, 2008b). This paper will examine the characteristics of the global art market and its implications for sociological theories of the arts.

\footnotetext{
* Professor of Sociology at the University of Pennsylvania.
}

Recebido em 3 out. 2008 e aprovado em 10 nov. 2008. 
In the past, sociologists of art distinguished between a reward system associated with high culture and a reward system associated with popular culture. In the reward system associated with high culture, to which contemporary art belonged, symbolic rewards were more important than material rewards, unlike the reward system for popular culture, such as film, television, and commercial music, in which material rewards were more important than symbolic rewards (Crane, 1976). Differences between the two reward systems included the nature of the content of the arts as compared to popular culture, specifically the ease with which the arts could be deciphered by audiences, and the artisanal production of art works in the studio as compared to the more industrialized production of popular works. In the work of Bourdieu (1993), who was very concerned by changes that have been taking place in the organization of the arts, these distinctions were embodied in the concepts of "the restricted field of production" as compared to "the field of large-scale cultural production." He argued that the increasing role of the market and financial criteria as a means for legitimating the arts jeopardized the survival of difficult works that did not immediately attract an audience in favor of works that were less demanding and more sensational (Cook, 2000).

During the past thirty years, the reward system underlying contemporary art has gradually been destabilized by two developments. First, the boundaries between high culture and popular culture have been steadily eroded in favor of a postmodernist perspective in which such distinctions are untenable. Popular culture, in the form of graffiti, cartoons, and celebrity icons, has become a major theme in the works of many successful artists.

Second, the sheer number of new artists and groups of artists with new aesthetic perspectives makes it increasingly difficult to evaluate their relative importance. Bauman (1997) argues that changes in contemporary arts are "random, dispersed and devoid 
of clear-cut direction" and that the importance of an art work is determined less by aesthetic elements than by the publicity and the notoriety that results from the work. To what extent, is globalization of the art market accelerating these changes by increasing the pressure of financial incentives for artists and the influence of superrich collectors on the assessment of artistic reputations.

\section{Postwar contemporary art markets: artistic communities and symbolic rewards}

Until the 1990s, major works of contemporary art were sold primarily in a few urban art worlds, including New York, Paris, London, and, to a lesser extent, Berlin. These elite art worlds embodied the standards against which less prestigious art worlds were compared. In elite art worlds, art works were displayed and sold in galleries. The auction market performed a secondary role, principally for major works by artists who were deceased. The financial value of a painting was less important than its consecration by a few major museums (such as the Museum of Modern Art in New York) whose curators performed important roles in putting together exhibitions of leading artists and purchasing important works. Artists were motivated less by financial gain than by their aesthetic goals and assessments of their works by their peers. The existence of an art world implied that art was a collective activity based on shared commitments to artistic conventions that defined what was considered to be art in a specific period and how it should be produced (Becker, 1982; Crane, 1987). Through their interactions with one another, artists who participated in the system or who aspired to participate in it developed a consensus about the worth of the works they were creating. New aesthetic criteria continually emerged as new groups of artists entered the art world. If these aesthetic criteria were strongly opposed to the aesthetic criteria of established artists, the term 'avant-garde' was often appropriate. 
These contemporary art communities were urban cultures (Crane, 1992). A recent article about postwar contemporary art in New York begins: "In the art world, geography is destiny" (Rosenberg, 2008). Specific neighborhoods in New York, such as Tenth Street, Greenwich Village, the East Village, and SoHo were locations where communities of artists lived and worked, exchanging ideas, and studying each other's work (Crane, 1987). For example, in the early years of Abstract Expressionism, the artists formed "a loose community based on mutual understanding and respect. Personal interactions were of great importance, for they gave rise to an aesthetic climate in which innovation and extreme positions were accepted and encouraged" (Sandler, 1976, p. 79). At the beginning of the twentieth century, art styles were also identified with specific neighborhoods in Paris, such as Montparnasse and Montmartre.

During the period when Abstract Expressionism was emerging, rewards were few. Visitors to art galleries in which paintings in that style were exhibited were rare. A leading art historian recalls that during the three years when he ran an influential cooperative gallery in New York, he sold only one work (Sandler, 1984, p. 12). Most of these artists worked for many years before achieving any economic success. Ironically, their paintings are now worth millions.

Artists valued their autonomy vis-à-vis collectors and dealers. They expected that members of the public who were actively participating in the art world, either as collectors or as dedicated viewers, would be aware of and would understand the conventions underlying their works. Most members of the general public were unlikely to understand these aesthetic conventions. Artists did not expect to be understood by the general public. An Abstract Expressionist painter, when asked "Whom is art for?", replied: "It is just for a few special people who are educated in art and literature. I would like to get rid of the idea that art is for everybody...The average man can get along with art" (Crane, 1987, p. 48). 
I will argue in this paper that social, cultural, and organizational changes in the past decade have produced a global art market whose influence outweighs that of the major urban art worlds and that is qualitatively and quantitatively different from previous art worlds. However, in spite of changes in its subject matter that appear to make it more accessible to the general public, contemporary art has not become more accessible or available to the general public for reasons that I will explain below.

\section{The global market for contemporary art}

\section{a) Social and economic structure}

The global market for contemporary art (Bellet, 2008) is centered around four major international art fairs, three national auction markets, a few major art dealers primarily from the U.S., Britain, and France, and a small group of super-rich collectors, several of whom are billionaires (see Chart 2). The market for contemporary art works (i.e. art works produced in the last twenty years) is a sub-set of the entire global art market which includes sales of art works from earlier periods. The value of transactions in the entire global art market has recently increased from 27,7 billion euros in 2002 to 43,3 billion euros in 2006, an increase in value of $56 \%$ (Ballet, 2008a).

In this market, art works are sold primarily in two types of locations: international art fairs and auction markets. The most important international art fairs take place once a year in New York (The Armory Show), London (Freize Art Fair), Basel (Art Basel), and Miami (Art Basel Miami Beach). Major art galleries display their wares at these fairs, permitting collectors, dealers, and other art market experts to identify new trends rapidly and to locate new talent. In Miami, about twenty 'satellite' fairs have sprung up around the major fair (Billard, 2007; Rosenberg, 2007). Basel also has its 
satellites (Bellet et al., 2007). Two of these major fairs were created recently, the Freize Art Fair in 2003 and Art Basel Miami Beach in 2001.

For artists and their galleries, the costs of participation in these events are very high but it is the only way to have access to the wealthiest collectors (Bellet, 2004). These events are a major source of information for both dealers and collectors. Rather than visiting dozens of galleries in cities, such as New York, London, and Paris, the major players in the global art market come together in one place. In a very brief period, collectors and dealers can spot trends and new movements and see works by new artists and new works by established artists. It is not surprising that these fairs have an enormous influence on prices in this market (Ellison, 2004).

Art works are also exhibited at urban art biennials. Art biennials are invited exhibitions; artists must be selected by curators in order to participate. Only a few, such as the Venice Biennale and Documenta at Kassel, are major centers for international art sales. As a result of the exponential growth of biennials, particularly in Asia, it has been estimated that there are now 112 biennials for contemporary art in cities all over the world (Lequeux, 2007).

Concomitantly with the emergence of art fairs, major auction houses, such as Christie's and Sotheby's, have become much more influential. ${ }^{1}$ In May 2008, six major auctions of contemporary art took place during a single week, setting numerous new records for the auction prices of specific artists. Because of the enormous importance in this new type of art market of the monetary value of art works, sales of art works at auction have become very significant because they establish publicly the value of specific art works. Consequently, auction houses, rather than museums, are defining contemporary art. Museums follow trends set in the international art market but they no longer have the financial means to set trends by buying major contemporary art works (Bellet, 2004). Museums 
even rely on galleries and collectors to help finance exhibitions of huge contemporary works that are difficult to transport and install (Finkel, 2007).

The auction prices of certain contemporary artists, for example, Jeff Koons, Damien Hirst and Lucien Freud, have soared in the past decade, along with the prices of leading artists of the postwar period, such as Andy Warhol and Francis Bacon (Sabbah, 2008). The highest price for a painting by a living artist is $\$ 33.6$ million (Lucien Freud, a British artist). The highest price for any postwar or contemporary artist (living or dead) is $\$ 86.3$ million (Francis Bacon, a British artist). The prices of specific paintings are often substantially higher than auction prices for major European artists of the past. For example, Warhol's 1963 painting, Green Car Crash, was sold at auction in 2007 for 71,7 million dollars, approximately the value of two good paintings by Raphael or Monet (Bellet, De Roux, 2007).

According to Artprice, the number of art works worth more than \$1 million was 154 in 1996; by 2007, the figure had increased over 8 times to 1,254 (Azimi, 2008). Why has the sale of contemporary art works and art works in general become so important? One explanation is the enormous amount of disposable wealth that is being created in the global economy, much of which is concentrated in the hands of a small group of businessmen and entrepreneurs (see below). Another explanation is that cities use art fairs and art biennials as a means of creating or changing their global image or even the identity of their country. For emerging countries, participation in the global art market is a way of indicating that they are contributing to global culture in a meaningful way. Contemporary art is becoming, like English, a universal language (Lequeux, 2007).

To summarize, according to an American art critic, "prices now determine reputations" (Tomkins, 2007b, p. 71). Prices are set 
through sales at auction houses. Traditional art gatekeepers, such as critics and museum curators, now perform less important roles in the reception of new art styles. The importance of contemporary artists is more likely to be measured in terms of their presence in the collections of mega-collectors rather than in prestigious museums. In the 1950s, when the contemporary art market was small and relatively inactive, a few critics, like Clement Greenberg, were very influential. At the present time, auction prices are the major factor. Only a few art dealers who have access to a high level of financial resources that enable them to participate in international art fairs and to invest in the production of art works are influential in this environment.

\section{b) The role of mega-collectors in the global contemporary art market}

Unlike art markets in the past, the global contemporary art market is driven by the tastes of very wealthy collectors who belong to a new class that has recently emerged in the global economy, the super-rich, defined as people whose personal fortunes are greater than $\$ 30$ million. It has been estimated that there are almost 95,000 people in this group in the entire world (Frétard, 2007). These people are avid consumers of luxury items of all kinds. In this context, art works become luxury items, along with jewelry, yachts, fancy cars, and haute couture. These collectors are so powerful that they have been called "mega-collectors". They are said to represent $80 \%$ of recent buyers of contemporary art. Consequently, the tastes of members of this new class are reshaping the characteristics of art objects and of the art markets in which they are sold. These mega-collectors can afford to finance galleries and to invest in the production of art works by leading artists. They often have teams of art experts and advisors who assist them with their purchases and may even build 
museums to house their own collections. At the same time, buyers of contemporary art are more geographically diverse than ever before with Russian and Chinese buyers becoming increasingly prominent (Melikian, 2007a; Melikian, 2008a). A list of major collectors of the most expensive examples of contemporary art appears in Chart 2.

Particularly important in this group are owners of hedge funds who tend to transpose into the domain of the arts their skills at speculation honed in the stock market. They establish 'positions' in certain artists whose market value they proceed to influence. They invest massively in these artists in order to raise the prices of their works and to increase the value of their own collections. When demand for the works of these artists increases, they restrict the supply of their work artificially, leading to higher prices and even greater demand (Bellet, De Roux, 2007).

Purchases by these wealthy collectors have not been affected by the recent financial crisis surrounding sub-prime mortgages in the United States and the subsequent sharp decline in stock market prices. A recent survey found that consumers worth more than $\$ 10$ million in assets, unlike those with fewer assets, planned to increase their spending on luxury goods in 2008 (Sullivan, 2008). The excellent results posted by a leading company in the luxury goods industry in 2007 are another indication that the very rich will continue to buy art along with other types of luxury goods, regardless of the financial outlook (Chayette, 2008). In January of 2008, as prices on world stock markets sank, prices of paintings at auction sales continued to rise (Melikian, 2008b).

Some mega-collections are huge. François Pinault, a French collector, owns 2,500 art works, as well as Christie's, the auction house. He works with ten consultants and specialists who assist him with purchases and conservation of the collection. An American collector, Eli Broad, has over 2000 works of modern and 
contemporary art (Wyatt, 2008). Broad's collection has doubled in size in the past five years. He keeps most of his art works in a foundation that lends them to museums. Martin Margulies owns 4000 art works. A billionaire, hedge-fund owner, Steven Cohen, bought close to one billion dollars worth of art between 2000 and 2006 (Tomkins, 2007b, p. 72).

The tastes and selections of these collectors undoubtedly affect the types of paintings that galleries choose to sell. These collectors are said to be "submerged in the present" unlike previous generations of collectors (Bellet, De Roux, 2007).

The European art critic, Souren Melikian, attributes the interest of contemporary collectors in contemporary art to their "urge to make a statement to others and to themselves... Aesthetics and contemplation no longer have anything to do with it" (Melikian, 2007e). He explains the growing unpredictability of auction prices by "the massive entry into the market of new buyers with little exposure to art (who are) unable to judge for themselves how good a work is" (Melikian, 2008a).

A prominent dealer claims that, in the 1970s, collectors did not belong to the business elite. They were psychiatrists and lawyers who established long-term relationships with dealers (Tomkins, 2007b, p. 72). Unlike today's megacollectors who tend to purchase art works very rapidly, often without having seen anything more than a digital version, these collectors frequently borrowed paintings and lived with them for several months before deciding whether or not to purchase them.

The emergence of this new group of collectors is accelerating changes, which were already under way, in the nature and production of art works, the nature of reward systems in art worlds, and the extent to which the concept of an avant-garde is still meaningful. 


\section{c) Contemporary art works: similarities and differences}

A relatively small number of contemporary artists, along with another larger group of artists who emerged in the postwar period, are the subject of intense speculation in the global art market (Bellet, 2004; Tomkins, 2007, p. 71) - see Chart I. Works by these artists have been sold for at least one million dollars on the auction market. The works of a somewhat larger number of contemporary artists have attained auction prices that range from $\$ 20,000$ to $\$ 1$ million. Most artists' works are auctioned for less than $\$ 20,000$ or not at all.

During the postwar period, the art market was dominated by a succession of art styles such as Abstract Expressionism, Minimalism, Pop Art and Neo-Expressionism (Crane, 1987). In an earlier study of the New York art market (Crane, 1987, p. 116), I found a similar pattern in which a few artists in these styles received high prices (over $\$ 100,000$ ) but most artists' works sold for less than $\$ 50,000$. Artists who received the highest prices were associated with a few powerful galleries. What is most notable is the change in the top prices which did not exceed \$550,000. Between 1970 and 1982, the median auction prices for Abstract Expressionist paintings, Pop art paintings and Minimalist works were, respectively, $\$ 128,750$, $\$ 25,000$, and $\$ 3,684$ (Crane, 1987, p. 116). Today, the highest auction price for an Abstract Expressionist painting is $\$ 50.4$ million; for a Pop art painting, $\$ 80$ million, and for a Minimalist work, $\$ 4.29$ million (see Chart 1). It is not surprising that the prices of these artists' works have increased over time, particularly since about half of them are dead. Death of a successful artist tends to bring about an increase in the value of his or her works because there is no possibility of additional works (Velthuis, 2003). What is surprising are the levels that prices of some of these artists have reached, in some cases substantially higher than current prices for traditional and early twentieth century paintings. What is even more surprising is that $50 \%$ of the contemporary artists have had works sold at auction 
for over $\$ 5$ million compared to $31 \%$ of the postwar artists. Like their counterparts in an earlier period, high-priced contemporary artists are represented by prestigious galleries but now one gallery in a major city is not sufficient. They are often represented by several galleries in cities in different parts of the world (see Chart 1).

Art works by contemporary artists are exceedingly diverse in style and subject matter (Melikian, 2008c; Melikian, 2007d). A large category of these artists share an outlook toward the nature of art which derives from the twentieth century French painter, Marcel Duchamp (d. 1968) as reinterpreted by Andy Warhol, a postwar artist. Rather than visual attributes or craftsmanship, the selection of the subject matter of the art work is the major element in making an artistic statement. These artists appear to compete with one another to find new types of subject matter, ranging from the bizarre and the hideous to the mundane and the kitsch, as exemplified by Damien Hirst's glass tanks holding animals in formaldehyde, Jeffrey Koon's huge steel heart in the shape of a valentine, or Richard Price's comical sentences in red letters on an olive background. ${ }^{2}$ Alternatively, contemporary artists recycle Duchamp's major contribution to art history, the "ready-made", the idea that the significance of an object depends on its context. A recent example of such a work is "No-one Ever Leaves" by Jim Hodges which consists of a leather jacket tossed in a corner with a spider web made of silver chains attached to the hem of the jacket and to the wall (Melikian, 2007b). 'Successful' subject matter can be interpreted as representing a concept or an idea which is more important than the subject matter itself.

In many cases, popular culture itself is the subject of contemporary art. There is a fusion of art and entertainment, as seen in the cases of the three artists mentioned above whose works are among those that have attained the highest prices in recent years. Hirst's latest work is an enormous skull encrusted with diamonds which, at $\$ 78$ million, ${ }^{4}$ is one of the most expensive art works in the 
world. Koons, who has been called "the superstar of kitsch", presents gigantic reproductions of children's toys (e.g. a puppy), cartoon monkey heads, and life-size images of naked girls from Playboy centerfolds. He recently produced a sculpture of the singer Michael Jackson, with his pet monkey. In his opinion, the contemporary artist does not need to know anything about art history. Prince's work recycles various forms of popular culture, including "advertising photographs... soft-core pornography, motorcyle-cult ephemera, pulp-novel covers, "Dukes of Hazzard"-era car parts, and celebrity memorabilia" (Schjeldahl, 2007, p. 90).

The traditional type of avant-garde which represented a relatively coherent movement consisting of a group of artists who were engaged in attacking and redefining the current aesthetic premises of art is notably absent. Some exhibitions of provocative and sensational art works generate a great deal of publicity but they do not represent genuine avant-garde movements.

Rather than being a proponent of an avant-garde, the successful contemporary artist can be characterized as an entrepreneur running a business which operates in a global market. As such, artists, like Damien Hirst, claim that they are not concerned with being original but with establishing brand names that represent a "trademark" style (Lury, 2005). Examples of Hirst's art works include a cow in formaldehyde and a container in which flies emerge from maggots, feed on a rotting cow's head, and die when they are electrocuted on an electric bar. He has also applied his 'brand name' to about 500 paintings of brightly colored spots on a white background that are made according to his exacting specifications by his assistants.

Instead of attempting to create original works that express his artistic identity, Hirst puts his name on art works that represent "assemblages and reassemblages, appropriations and incorporations" (Lury, 2005, p. 95). These assemblages may incorporate objects that 
have been copyrighted by others. He was sued for copying one of his son's toys and lost the case. His 'brand name' represents a distinctive or 'trade-mark' style that is difficult to imitate and which is intended to inspire 'brand loyalty' (Lury, 2005, p. 96).

The Japanese artist-entrepreneur, Takashi Murakami, goes even further in this direction (Schjeldahl, 2008). A recent retrospective of his work at the Brooklyn Museum in New York, entitled, appropriately, "CMurakami”, included an actual Louis Vuitton shop that sold handbags and other luxury goods, all designed by the artist. In addition to his art works, Murakami has produced goods for Louis Vuitton that have earned hundreds of millions of dollars for the luxury goods company. He owns his own company with branches in Tokyo and New York that employs about a hundred workers to make art works that constitute the Murakami brand. His paintings are characterized by "apocalyptic violence, saccharine cuteness, resurgent nationalism, and... perverse sex (Schjeldahl, 2008, p. 68).

Richard Prince's art works are based on appropriation of images from popular culture (see examples above). He also copies works by established post-war artists, such as Jasper Johns, Robert Rauschenberg, Ed Ruscha, and Willem de Kooning (Schjeldahl, 2007). He was recently given a large retrospective at the Guggenheim Museum in New York.

Jeffrey Koons produces extremely large and very expensive works, such as a forty foot high likeness of a West Highland terrier, called "Puppy" (Tompkins, 2007a), with a large staff of assistants. A work in progress is a working reproduction of a 1943 Baldwin locomotive that will be suspended outside a museum in Los Angeles. The project is expected to cost $\$ 20$ million.

How do these artists conceptualize the audience for their works? Both Hirst and Mirakami appear to see the audience as a 
homogenous mass, not unlike the way Hollywood sees its audience for blockbusters. Hirst describes the effects of his formulaic paintings of spots on viewers as being similar to the effects of anti-depressive pills. He has been quoted as saying: "The spot paintings are an unfailing formula for brightening up people's fucking lives" (Lury, 2005, p. 100). In other words, he believes that these paintings have the same effect on everyone and is not interested in any variations in the public's reactions to this work. Elsewhere, he has said that he places his work in closed boxes to keep viewers out (Lury, 2005, p. 102). Any personal touches added by viewers would "fuck it up".

According to one art critic, Murakami's aim "is to control and standardize aesthetic experience, forcing viewers into an infantile mold of rote response. He offers us relief from the worry... of thinking and feeling as individuals - a blissful submersion in mechanical effect, the same for everybody" (Schjeldahl, 2008, p. 70).

Koons takes a somewhat different stance toward the viewer. Following Marcel Duchamp, for whom the viewer was an important part of the creative process, Koons claims to be more concerned about the viewer than about the art work but in contrast to Duchamp's idea that the role of the viewer was to complete the work by interpreting its meaning and its place in art history, Koons says (Tompkins, 2007a, p. 67): "I just try to do work that makes people feel good about themselves, their history and their potential." His goal is "to help people accept their own cultural background." He believes that contact with his work makes people "feel very good" (p. 66). In other words, his art works are intended to have a positive effect on viewers and to require a minimum of input from them. Koons does not claim to be familiar with art history and he does not expect his viewers to know anything about art either, although he may, at times, include details that represent a nod to avant-gardes of the past. Superimposed on his painting, "Three Elvises", which is based on a Playboy centerfold, is a crab's claw, a motif used by Salvador Dali in the 1930s. 
The remaining artists on the list of high-priced contemporary artists fall into two groups: Western artists who are working in postwar or traditional art styles and Asian artists who are benefiting from a current fad for Asian and particularly Chinese artists whose work has become more visible in the global environment. For example, Peter Doig produces representational paintings of landscapes in a traditional style. Mark Grotjahn does bold geometric paintings. Robert Gober is an installation artist whose work often depicts body parts or works that follow in the Duchamp tradition, such as a storm drain featured as an art object.

Among the Asian artists, Yoshitomo Nara, a Japanese Pop artist, does paintings which are similar to the works of Murakami and Prince in their reliance on images and themes from popular culture. Yoshitomo Nara depicts cute and colorful images of children which he infuses with incongruous imagery that suggests a potential for violence. Some of the Chinese artists are more provocative. One of Yue Minjun's works, "Execution", shows four men, almost naked, laughing while two others simulate the gestures of a firing squad (Melikian, 2007c). Cai Guo-Qiang makes gunpowder drawings from fuses and explosive powers, laid on paper and ignited (Micucci, 2007). Like his Western counterparts, Cai Guo-Qiang also does gigantic installations, such as an arc of 99 life-size replicas of wolves that appear to be leaping head on into a glass wall and a series of nine cars, some of which were recently suspended from the top of the rotunda at the Guggenheim Museum in New York. It took a month to install an exhibition of his work at the museum.

Maurizio Cattelan is the exception in the group, using his art to question and to satirize contemporary mores. His most expensive work is a sculpture depicting Pope John Paul II struck down by a meteorite. His next most expensive work shows an elephant in a Klu Klux uniform. Another controversial consists of three children (in resin) being hung from a tree. He too does not construct his works; they are made by assistants. 
d) The production of art in the global contemporary art market

The production of art works in this market often involves huge investments by dealers and collectors and large staffs of assistants or, in many cases, separate firms, that actually produce the art works under the artist's direction. As we have seen, Jeff Koons and Takashi Murakami employ between eighty and one hundred people to produce their art works (Tomkins, 2007a; Schjeldahl, 2008). Each of Koons' canvases may have three people working on it at the same time, "copying from digital printouts in which the colors are marked and identified by number" (Tompkins, 2007a, p. 6).

When art works are very large, industrial, labor intensive or time-consuming, professional art fabricators construct them for the artist (Finkel, 2008, Fineman, 2006). Many artists no longer possess the technical skills to produce the works they imagine. Minimalist artists in the 1960s frequently had their complicated sculptures produced by industrial firms but, today, the practice of having art works constructed by firms that specialize in this type of work is much more widespread.

Installing such works in an urban setting can be a formidable challenge. In some cases, the art works are so complicated that as many as 45 different contractors may be required to assemble a work. Installation of Jeff Koons, giant sculpture "Puppy" at the Rockefeller Center in May 2000, was a three-week-long process that involved about 100 riggers, planters, engineers, and studio assistants (Fineman, 2006). Installation of Damien Hirst's "School: The Archeology of Lost Desires, Comprehending Infinity, and the Search for Knowledge" in the lobby of the Lever House in New York took two years at a cost of $\$ 1$ million (Vogel, 2007). According to the artist, the sketch for the art work took ten minutes.

The cost of producing art works and of transporting and installing them either temporarily or permanently has escalated to 
the extent that galleries and collectors often contribute all or part of these expenses. In other words, some collectors will co-produce art works along with the artist and the gallery. In these situations, several copies of the work are likely to be produced. The copies are divided between the artist, the collector, and the gallery (Bellet, 2005). For example, Jeffrey Koons' huge (3 meters) "Balloon Dog" exists in five versions in different colors (Finkel, 2008), as does his steel heart, "Hanging Heart". His "Michael Jackson and Bubbles" exists in three versions (Azimi, 2007b).

The increasing division of labor between "art workers" and "art thinkers" raises the question of what is the role of a contemporary artist. Jeffrey Deitch, who owns a gallery in SoHo, suggests that we are moving toward an understanding of the artist as a philosopher rather than as a craftsman (Fineman, 2006). Deitch says: "The artist's idea and vision are prized, rather than the ability to master the crafts that support the work." Maurizio Cattelan says (Cirrias, 2005): "The idea that the artist manipulates materials is not something that I agree with. I don't design. I don't paint. I don't sculpt. I absolutely never touch my works."

However, artists, like fashion designers, take the entire credit for works that are in fact the result of collective activity. Katy Siegel, an art critic and professor of contemporary art history, speaks of "a real class divide in the art world between the art workers and the art thinkers" (Fineman, 2006). Although a few of Damien Hirst's assistants have gone on to careers as artists, hundreds of aspiring artists are relegated to careers in which they fabricate the works of a few, highly successful artists.

The emphasis on art works as ideas rather than as objects is indicated by the fact that collectors often buy art works without seeing the work itself except in digital form on the Internet (Tomkins, 2007b, p. 72). In the past, when reproductions of art works were invariably considered to be inferior to the original, buying an art work without 
having seen it would have been unthinkable. The current practice of buying on the basis of digital images suggests that the value of an art work now depends on the discourse surrounding the work in the media rather than on its visual characteristics and quality (Melikian, 2008c). Melikian (2007e) states: "This bewildering diversity at all financial levels of the contemporary art currently in highest demand demonstrates that visual considerations have only limited importance in the making of prices. Ideas, names, some would say the volume of propaganda, are the factors leading to financial triumph."

The contemporary art world itself has been described as an industry, comparable to the film industry or the fashion industry. The dealer, Jeffrey Deitch, has been quoted as saying: "The art world used to be a community, but now it's an industry. It's not just a market - it's a visual culture industry, like the film industry or the fashion industry, and it merges with both of them" (Tomkins, 2007b, p. 72).

Jasper Johns, a leading artist of the postwar period, recently told an interviewer that he still executes all his work by hand. He does not rely on assistants or on computers. He added the following comment: "It's a different art world from the one I grew up in. Artists...are more aware of the market than they once were. There seems to something in the air that art is commerce itself' (Vogel, 2008).

\section{Contemporary art and fashion}

One consequence of these changes is that art and fashion, which were formerly quite distinct as sociological concepts, are becoming more alike. The reception of new art works is becoming more similar to the reception of new trends in fashion. Like fashion, art is increasingly driven by commercial rather than aesthetic considerations. Specifically, it is driven by the eclectic and often superficial tastes of a new cohort of exceedingly wealthy collectors. 
It is highly significant that the global art world has switched to a system of seasonal sales through international art fairs that is analogous to the seasonal shows of fashion collections that take place every year in Milan, Paris, London, and New York. Certain artists are said to be 'in fashion' at each art fair. Knowing in advance who these artists will be can generate profits for those who already own their works. Motives for purchasing art have been compared to motives for purchasing fashionable clothes.

The abrupt rise in the past two years of prices of contemporary Chinese art and in sales of contemporary Chinese art suggests the existence of a fad that may be about to peak (Pomfret, 2008; Kolesnikov-Jessup, 2008). The value of Chinese art sold in 2007 increased by 41 percent in comparison with the previous year. The price per square foot of works by one hundred top Chinese contemporary artists increased by $40 \%$ in 2007 . Five out of the sixteen contemporary artists (31\%) with auction prices over $\$ 1$ million are Chinese (see Chart 1). At the beginning of this decade, Quemin (2006) found that it was very difficult for Asian artists to succeed in the Western art market. He concluded that the art market was not global.

There are also analogies between fashion and art in the relevance of the concept of a brand. In the fashion business, brands are used to attach images to luxury goods in order to convince the buyer that she is purchasing a new but valuable commodity. The role of the fashion designer has become subordinate to the role of the brand that represents the company which employs the designer. Many young designers are unable to start their own businesses and work for companies which are controlled by powerful conglomerates that restrict their creative autonomy and evaluate their work in relation to the success of their brands.

It is not an accident that artists, such Damien Hirst and Takashi Murakami, claim that they have created brands. The concept also 
appears to be relevant to much of what Jeffrey Koons and Richard Prince are doing and could probably be extended to many others. In the case of the artist, the latter controls a company which churns out luxury goods for a highly profitable, niche market. Like fashion designers, whose works are also the result of collective activity, the artist takes all the credit for these industrial productions.

\section{Conclusion}

The subject of this paper has been a small but very important, highly visible, and extremely profitable segment of the art market, specifically the global art market. As such, it seems likely that it is setting the standards for urban art markets that continue to exist in many large cities in the United States, Europe, and increasingly in Asia. To some extent, these urban art markets piggyback on international art fairs that bring large numbers of dealers and collectors to certain cities.

The nature of the reward system surrounding the production of this type of art is the antithesis of the reward system that existed in the art world at the beginning of the postwar period. Access to the global art market is available only to very rich collectors, the most successful and powerful art dealers, and major auction houses. This relatively closed circuit has produced a type of art that tends to recycle cultural images and symbols that have already been widely disseminated in popular culture and the media. In spite of the fact that their content is readily accessible to a larger public, these art works tend to have a relatively limited and elite audience. Many of the works are located in private collections. They reach a somewhat larger audience if they are purchased or exhibited by museums or if the collectors create viewing spaces for their works.

The huge sums available for purchase and for investment in these types of art works has produced a predilection for extremely 
large and expensive works that are manufactured industrially or semi-industrially, a system that requires the employment of large numbers of artists in relatively menial roles. Other artists provide high-level technical skills for the production of these works. Neither group receives any type of recognition or reward, other than wages. For the artists who design the art works and who profit enormously from their production in terms of both economic and symbolic rewards, aesthetic issues are minimized in comparison to the problems of maximizing sales and profit in order to maintain these systems of industrial production. Communities of artists are virtually nonexistent.

The global art market is an illustration of the way in which the globalization of markets is expanding economic and cultural inequality by increasing the wealth and privileges of small segments of the world's population at the expense of the remainder. This in turn has produced a high-end enclave in the art market in which very expensive art works circulate among extremely wealthy collectors whose tastes shape the symbolic and material aspects of the products. Sales at auction houses provide reliable indicators of demand for these products. Bypassing urban art markets and art communities, these transactions take place at a small number of international art fairs under the aegis of a small group of powerful dealers. As is the case in other global markets, serious players in this market require high levels of disposable income and high levels of capital for investment.

\section{Notes}

1 Christie's and Sotheby's constitute 80 percent of the entire international fine art auction business (Ellison, 2004). They have branches in London, New York, and Paris.

2 The sentences read: "A pink elephant, a green kangaroo and two yellow snakes strolled up to the bar. 'You're a little early, boys,' said the bar 
tender. 'He ain't here yet." This work was recently auctioned for $\$ 1.38$ million (Melikian, 2007d).

3 This work sold at auction in 2007 for $\$ 689,600$ (Melikian, 2007b).

4 This price represents a direct sale to a collector rather than an auction sale.

Reflexões sobre o mercado global de arte: implicações para a Sociologia da Cultura

Resumo: $O$ artigo examina as mudanças recentes nos mundos artísticos a partir das características do mercado de arte global e suas implicações para as teorias sociológicas das artes. Para isto, focaliza a correlação estabelecida entre o declínio das vanguardas artísticas e os modos como se fazem tênues as fronteiras entre alta cultura e cultura popular. Nesse sentido, discute e analisa a influência exercida, cada vez mais, por atores localizados em países como Estados Unidos, Inglaterra, Alemanha, França e, mais recentemente, China. Conclui a respeito do quanto o mercado global de arte pode ser ilustrativo dos processos em que a globalização dos mercados expande a desigualdade econômica e cultural, favorecendo o privilégio de pequenos segmentos sociais no mundo contemporâneo.

Palavras-chaves: mudanças; mundos artísticos; mercado de arte global; vanguardas artísticas; alta cultura; cultura popular; fronteiras; teorias sociais sobre as artes.

\section{References}

AZIMI, R. Cinq artists vivants au sommet. Le Monde:argent! p. 8, March 12,2007 a.

. Jeff Koons, superstar du kitsch. Le Monde:argent! p. 10, Nov. 11-12, 2007b.

L'insatiable appétit des collectioneurs des pays émergents. Le Monde: argent! p. 2, Jan. 20-21, 2008.

BAUMAN, Z. Postmodernity and its discontents. New York: New York University Press, 1997. 
BECKER, H. S. Art worlds. Berkeley, CA: University of California Press, 1982.

BELLET, H. La Foire de Bâle frappée par l'explosion des prix de l'art contemporain. Le Monde, p. 32, June 22, 2004.

. La folie des mégacollectionneurs d'art contemporain. Le Monde, p. 20-21, Dec. 1, 2005.

Ventes records à l'arraché à New York. Le Monde, p. 25, Nov. 17, 2007a.

. Démesure à la foire de Miami, entre Salons d'antan et galleries d'aujourd'hui. Le Monde, p. 25, Dec. 8, 2007b.

. Maastricht, foire de la démesure, expose un secteur florissant. $L e$ Monde, p. 23, March 11, 2008a.

. La France dépassée par la Chine. Le Monde, p. 23, April 3, 2008b.

BELLET, H.; ROURE, B. Les vedettes de l'art trash au Centre Pompidou. Le Monde, p. 18, Feb. 20-21, 2005.

BELLET, H.; De ROUX, E. Les nouveaux collectionneurs. Le Monde, p. 2, July 17, 2007.

BELLET, H.; DAGEN, P.; LEQUEUX, E. Art contemporain: un grand tour en quatre étapes. Le Monde, p. 24-25, June 8, 2007.

BILLARD, M. An avalanche of art: Miami Beach fair spurs 20 satellite shows. International Herald Tribune, p. 22, Nov. 30, 2007.

BOURDIEU, P. The field of cultural production. Cambridge: Polity, 1993.

BÜRGER, P. Theory of the Avant-Garde. Translated by Michael Shaw. Minneapolis, MN: University of Minnesota Press, 1984.

CALDWELL, J. C. Televisuality: style, crisis and authority in American television. New Brunswick, NJ: Rutgers University Press, 1995.

CHAYETTE, S. En dépit d'un euro fort, LVMH annonce un résultat record en 2007. Le Monde, p. 14, Febuary 7, 2008.

CHIFFRES: 74 millions d'euros. Le Monde, p. 29, Sept. 1, 2007.

COOK, R. The mediated manufacture of an 'avant-garde: a Bourdieusian analysis of the field of contemporary art in London, 1997-9. In: 
FOWLER, B. (Ed.). Reading Bourdieu on Society and Culture. Oxford: Blackwell, 2000.

CORRIAS, P. Artists par hazard, milliardaire malgré lui. Courrier International, n. 745, p. 38-39, 10 au 16 février, 2005.

COTTER, H. Collectives blurring the lines of who makes modern art. International Herald Tribune, p. 22, March 8, 2006.

Is Whitney's subdued fair a sign of the times? International Herald Tribune, p. 9, March 11, 2008.

CRANE, D. Reward systems in art, science, and religion. American Behavioral Scientist, n. 19, p. 719-734, 1976.

CRANE, D. The Transformation of the Avant-Garde: The New York Art World, 1940-1985. Chicago, IL: University of Chicago Press, 1987.

.High culture versus popular culture revisited: a reconceptualization of recorded cultures. In: LAMONT, M.; FOURNIER, M. (Eds.). Cultivating differences: symbolic boundaries and the making of inequality. Chicago: University of Chicago Press, 1992. p. 58-74.

. Fashion and its social agendas: class, gender, and identity in clothing. Chicago, IL: University of Chicago Press, 2000.

. Avant-gardes and artists. In: INTERNATIONAL Encyclopedia of the Social and Behavioral Sciences. Oxford: Pergamon-Elsevier Science, 2002. v. 2, p. 1015-19.

DUNN, R. Postmodernism: populism, mass culture, and avant-garde. Theory, Culture and Society, n. 8, p. 111-135, 1991.

ELLISON, H. Opportunity knocks as art fairs mushroom. International Herald Tribune, p. II, Dec. 20, 2004.

FINEMAN, M. The artisans who make large artworks possible. Le Monde: The New York Times, p. 8, May 13, 2006.

FINKEL, J. Museums solicit dealers' largess. The New York Times, Nov. $18,2007$.

. A company at the ready when artists think big. The New York Times (Le Monde edition), p. 8, May 3, 2008.

FINNEY, H. C. Art production and artists' careers: the transition from "outside" to "inside". In: ZOLBERG, V. L.; CHERBO, J. M. (Eds.). Outsider art: contesting boundaries in contemporary art. Cambridge: Cambridge University Press, 1997. p. 73-84 
FRETARD, D. L'ivresse de l'utraluxe. Le Monde 2, p. 22, Dec. 15, 2007.

GALLOWAY, D. Inside a German artist's idiosyncratic universe. International Herald Tribune, p. 20, July 18, 2006.

HUSTON, L. The theory of the avant-garde: an historical critique. Canadian Review of Sociology \& Anthropology, n. 29, p. 72-86, 1992.

KAPLAN, E. A. Rocking round the clock. New York: Methuen, 1987.

KOLESNIKOV-JESSOP, S. Is a correction coming for Asian art market? International Herald Tribune, p. 14, May 31-June 1, 2008.

Le QUEUX, E. Toutes les grandes villes du monde veulent en être. Le Monde, p. 25, June 8, 2007..

LURY, C. Contemplating 'a self-portrait as a pharmacist': a trade mark style of doing art and science. Theory, Culture \& Society, n. 22, p. 93-110, 2005.

MELIKIAN, S. Works by Warhol bring in $\$ 137$ million. International Herald Tribune, p. 20, May 18, $2007 \mathrm{a}$.

. Yes, it's art: just ask the experts - and the buyers. International Herald Tribune, p. 12, May 19-20, $2007 \mathrm{~b}$.

. Breakthrough by Chinese artists opens new vistas. International Herald Tribune, Oct. 20-21, p. 11, 2007c.

. \$325 million sale reflects buoyant market. International Herald Tribune, p. 11, Nov. 15, $2007 \mathrm{~d}$.

. Bacon and Koons lead 4315.9 million sale. International Herald Tribune, p. 10, Nov. 16, 2007e.

. Behind stellar sales, a dangerous game. International Herald Tribune, p. 10, Jan. 19-20, 2008a.

. Drawings, porcelain and paintings soar. International Herald Tribune, p. 9, Jan. 26-27, 2008 b.

Sotheby's sale sets a record: 95 million pounds. International Herald Tribune, February 29, 2008c.

MICUCCI, D. U.S. museums and dealers catch the Asian fever. International Herald Tribune, p. 12, Oct. 13-14, 2007. 
PAGANI, J. Mixing art and life: the conundrum of the avant-garde's autonomous status in the performance art world of Los Angeles. Sociological Quarterly, n. 42, p. 175-203, 2001.

POGGIOLI, R. The Theory of the Avant-Garde. Translated by Gerald Fitzgerald. Cambridge, MA: Harvard University Press, 1968.

POMFRET, J. Looking at Asian art for the next big jackpot. International Herald Tribune, p. 17, February 4, 2008.

QUEMIN, A. Globalization and mixing in the visual arts: an empirical survey of 'high culture' and 'globalization'. International Sociology, n. 21, p. 522-550, 2006 .

RIDING, A. 'Ethically sourced' art, for a mere $\$ 100$ million. International Herald Tribune, p. 2, June 9-10, 2007.

ROSENBERG, H. Collective, ideological, combative. In: HESS, T. B.; ASHBERY, J. (Eds.). Avant-Garde Art. London: Collier Books, Collier-Macmillan., 1968.

ROSENBERG, K. Where serious art meets raucousness. International Herald Tribune, p. 22, Dec. 11, 2007.

. New York cool: a transitional generation is given its due. International Herald Tribune, p. 9, April 26-27, 2008.

SABBAH, C. Une pause salutaire? Le Monde: argent! p. 2, Jan. 20-21, 2008.

SANDLER, I. The triumph of American painting: a History of Abstract Expressionism. New York: Harper and Row, 1976.

. Tenth Street then and now. In: THE EAST Village Scene. Philadelphia, PA.: Institute of Contemporary Art, University of Pennsylvania, 1984. p. 10-19.

SCHJELDAHL, P. The joker: Richard Prince at the Guggenheim. The New Yorker, p. 90-92, Oct. 15, 2007.

. Buying it: a Takashi Murakami retrospective. The New Yorker, 68-70, April 14, 2008.

SULLIVAN, A. For durable growth, luxury brands covet the recession proof. International Herald Tribune, p. 19, March 8-9, 2008. 
TAYLOR, J. Futurism: the avant-garde as a way of life. In: HESS, T. B.; ASHBERY, J. (Eds.). Avant-Garde Art. London: Collier Books, Collier-Macmillan, 1968.

TOMKINS, C. The turnaround artist: Jeff Koons, up from banality. The New Yorker, p. 58-67, April 23, 2007a.

. A fool for art: Jeffrey Deitch and the exuberance of the art market. The New Yorker, p. 64-75, Nov. 12, $2007 \mathrm{~b}$.

VELTHUIS, O. Symbolic meanings of prices: constructing the value of contemporary art in Amsterdam and New York galleries. Theory and Society, n. 32, p. 181-215, 2003.

VOGEL, C. Hirst unveils his \$10 million 'School'. International Herald Tribune, p. 7, Nov. 13, 2007.

. Jasper Johns: color in shades of gray. International Herald Tribune, p. 22, Feb. 6, 2008.

WHITE, H.; WHITE, C. Canvases and careers. New York: Wiley, 1965.

WYATT, E. A philanthropist opts not to give it all away. International Herald Tribune, p. 20, Jan. 10, 2008.

\section{Chart 1 - The global art market: leading artists and highest auction prices: postwar and contemporary art}

Leading Artists: Postwar (with highest auction prices as of 2008)*

\begin{tabular}{|l|c|c|l|}
\hline \multicolumn{1}{|c|}{ Artist } & Country & Year of born/death & \multicolumn{1}{|c|}{ Price } \\
\hline Ad Reinhardt & US & d. 1967 & $\$ 2.1 \mathrm{~m}$ \\
\hline Adolf Gottlieb & US & d. 1974 & $\$ 5.8 \mathrm{~m}$ \\
\hline Agnes Martin & US & d. 2004 & $\$ 2.5 \mathrm{~m}$ \\
\hline Alexander Calder & US & d. 1976 & $\$ 4.7 \mathrm{~m}$ \\
\hline Andy Warhol & US & d. 1987 & $\$ 71.7 \mathrm{~m}$. \\
\hline Anselm Kiefer & FRG & b. 1945 & $\$ 1.6 \mathrm{~m}$ \\
\hline Arshile Gorky & US & d. 1948 & $\$ 2.15 \mathrm{~m}$ \\
\hline Barnett Newman & US & d. 1970 & $\$ 4.6 \mathrm{~m}$ \\
\hline Brice Marden & US & b. 1938 & $\$ 4.29 \mathrm{~m}$ \\
\hline Bridget Riley & UK & b. 1931 & $\$ 2.79 \mathrm{~m}$. \\
\hline Bruce Nauman & US & b. 1941 & $\$ 1.3 \mathrm{~m}$ \\
\hline
\end{tabular}

* Includes artists with auction prices of $\$ 1 \mathrm{~m}$ or above. 


\begin{tabular}{|c|c|c|c|}
\hline Artist & Country & Year of born/death & Price \\
\hline Carl Andre & US & b. 1935 & $\$ 2.3 \mathrm{~m}$ \\
\hline Claes Oldenburg & US & b. 1929 & $\$ 1.5 \mathrm{~m}$ \\
\hline Clyfford Still & US & d. 1980 & $\$ 12.5 \mathrm{~m}$ \\
\hline Cy Twombly & US & b. 1928 & $\$ 5.38 \mathrm{~m}$ \\
\hline Dan Flavin & US & d. 1996 & $\$ 1.35 \mathrm{~m}$ \\
\hline David Smith & US & d. 1965 & $\$ 2.1 \mathrm{~m}$ \\
\hline Donald Judd & US & d. 1994 & $\$ 3.75 \mathrm{~m}$ \\
\hline Ed Ruscha & US & b. 1937 & $\$ 3.5 \mathrm{~m}$ \\
\hline Ellsworth Kelly & US & b. 1923 & $\$ 1.6 \mathrm{~m}$ \\
\hline Eva Hesse & US & d. 1972 & $\$ 1.49 \mathrm{~m}$ \\
\hline Francis Bacon & UK & d. 1992 & $\$ 86.3 \mathrm{~m}$ \\
\hline Frank Stella & US & b. 1936 & $\$ 2.5 \mathrm{~m}$ \\
\hline Georg Baselitz & FRG & b. 1938 & $\$ 4.1 \mathrm{~m}$ \\
\hline Gerhard Richter & FRG & b. 1932 & $\$ 13.5 \mathrm{~m}$ \\
\hline Hans Hoffman & US & d. 1966 & $\$ 3.8 \mathrm{~m}$ \\
\hline Jasper Johns & US & b. 1930 & $\$ 80 \mathrm{~m}$ \\
\hline Jean Arp & FRG-France & d. 1966 & $\$ 1.4 \mathrm{~m}$ \\
\hline Jean Dubuffet & France & d. 1985 & $\$ 3.2 \mathrm{~m}$ \\
\hline Jean-Michel Basquiat & US & d. 1988 & $\$ 14.6 \mathrm{~m}$ \\
\hline Joan Mitchell & US & d. 1992 & $\$ 4.5 \mathrm{~m}$ \\
\hline John Chamberlain & US & b. 1927 & $\$ 1 \mathrm{~m}$ \\
\hline Keith Haring & US & d. 1990 & $\$ 1.6 \mathrm{~m}$ \\
\hline Lee Krasner & US & d. 1984 & $\$ 2.8 \mathrm{~m}$ \\
\hline Lucien Freud & UK & b. 1922 & $\$ 33.6 \mathrm{~m}$ \\
\hline Lucio Fontana & Italy & d. 1968 & $\$ 19.6 \mathrm{~m}$ \\
\hline Mark Rothko & US & d. 1970 & $\$ 72.4 \mathrm{~m}$ \\
\hline Philip Guston & US & d. 1980 & $\$ 2.1 \mathrm{~m}$ \\
\hline Piero Manzoni & Italy & d. 1963 & $\$ 9 \mathrm{~m}$ \\
\hline Richard Diebenkorn & US & d. 1993 & $\$ 3.36 \mathrm{~m}$ \\
\hline Richard Serra & US & b. 1939 & $\$ 1.3 \mathrm{~m}$ \\
\hline Robert Indiana & US & b. 1928 & $\$ 2.5 \mathrm{~m}$ \\
\hline Robert Motherwell & US & d. 1991 & $\$ 2.9 \mathrm{~m}$ \\
\hline Robert Rauschenberg & US & d. 2008 & $\$ 13 \mathrm{~m}$ \\
\hline Robert Smithson & US & d. 1973 & $\$ 3.8$ \\
\hline Roy Lichtenstein & US & d. 1997 & $\$ 7.8 \mathrm{~m}$ \\
\hline Sam Francis & US & d. 1994 & $\$ 5.19 \mathrm{~m}$ \\
\hline Sigmar Polke & FRG & b. 1941 & $\$ 1 \mathrm{~m}$ \\
\hline Tom Wesselmann & US & b. 1931 & $\$ 9.5 \mathrm{~m}$ \\
\hline Wayne Thiebaud & US & b. 1920 & $\$ 1.9 \mathrm{~m}$ \\
\hline Willem de Kooning & US & d. 1997 & $\$ 20.6 \mathrm{~m}$ \\
\hline Yves Klein & France & d. 1962 & $\$ 23.56 \mathrm{~m}$ \\
\hline
\end{tabular}




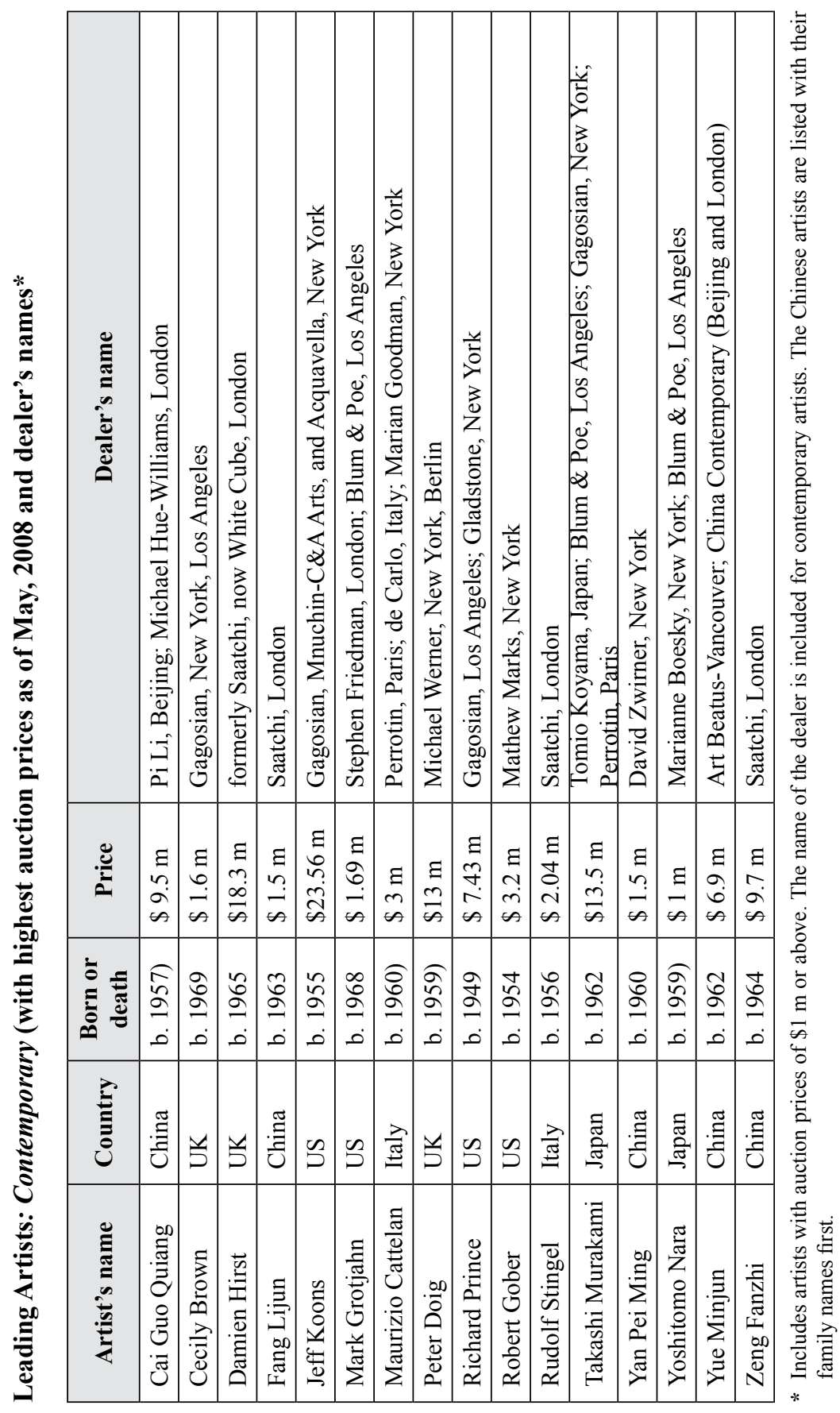




\section{Chart 2 - The global art market: collectors, dealers, and exhibition sites}

\section{Leading International Art Fairs}

Armory Show (New York)

Art Basel (Switzerland)

Art Basel Miami Beach

Freize Art Fair (London)

\section{Leading International Art Shows}

Documenta (FRG)

Tefaf (Maastricht)

Berlin Biennale

Venice Biennale

\section{Leading Contemporary Art Collectors}

\begin{tabular}{|c|c|c|}
\hline Name & Country & Main professional activity \\
\hline Francesca van Habsburg & Austria & The Arch Foundation \\
\hline Bernard Arnault & France & Luxury goods \\
\hline Agnes B & France & Fashion business \\
\hline Antoine De Galbert & France & Museum director \\
\hline *François Pinault & France & Retail, luxury goods \\
\hline Ingvild Goetz & FRG & Art dealer \\
\hline Benedikt Taschen & FRG & Publisher \\
\hline Dakis Joannou & Greece & Industrialist \\
\hline Miuccia Prada & Italy & Fashion design \\
\hline Eugenio Lopez Alonso & Mexico & Business \\
\hline Joao Oliviera-Rendeiro & Portugal & Banker \\
\hline Michel Ringier & Switz & Publishing \\
\hline Pierre Huber & Switz. & Art dealer \\
\hline *Charles Saatchi & UK & Advertising, art dealer \\
\hline *Anita and Poju Zabludowicz & UK & Real estate \\
\hline Abigail and Leslie Wexner & US & The Wexner Center for the Arts \\
\hline Aby Rosen & US & Real estate \\
\hline Adam Lindemann & US & Media \\
\hline Adam Sender & US & Hedge fund manager \\
\hline Daniel Loeb & US & Hedge fund manager \\
\hline David Ganek & US & Hedge fund manager \\
\hline David Geffen & US & Film and music producer \\
\hline Dominique Levy & US & Art dealer \\
\hline Eileen Norton & US & Norton utilities \\
\hline
\end{tabular}




\begin{tabular}{|l|c|l|}
\hline \multicolumn{1}{|c|}{ Name } & Country & \multicolumn{1}{|c|}{ Main professional activity } \\
\hline *Eli Broad & US & Real estate, financier \\
\hline Frank Cohen & US & Retail \\
\hline Javier Peres & US & Art dealer \\
\hline Larry Gagosian & US & Art dealer \\
\hline Martin Margulies & US & Real estate \\
\hline Michael Ovitz & US & Film producer \\
\hline Norman Braman & US & Auto magnate \\
\hline Peter Brant & US & Real estate \\
\hline Robert Mnuchin & US & Art dealer \\
\hline Rosa \& Carlos De La Cruz & US & Business \\
\hline Rubell Family & US & Hotels \\
\hline *Si Newhouse & US & Publisher \\
\hline Steve Wynn & US & Las Vegas casinos \\
\hline *Steven Cohen & US & Hedge fund manager \\
\hline
\end{tabular}

*Billionaire (Forbes.com)

\section{Leading Dealers: Contemporary Art}

William Acquavilla (US)

Marc Blondeau (Switz.)

Blum \& Poe (US)

Mary Boone (US)

Spencer Brownstone (US)

Massimo de Carlo (Italy)

Paula Cooper (US)

Elaine Dannheisser (US)

Jeffrey Deitch (US)

Antony D'Offay (UK)

Larry Gagosian (US)

Barbara Gladstone (US)

Marion Goodman (US)

Pierre Huber (France)

Emmanuel Perrotin (France, US)

Charles Saatchi (UK)

Philippe Ségalot (France, US)

Sperone Westwater (US)

\section{Leading Auction Houses}

Christie's (London, New York, Paris)

Hôtel Drouot (Paris)

Sotheby's (London, New York, Paris). 